ISSN 0103-5150

Fisioter. Mov., Curitiba, v. 28, n. 4, p. 779-791, Oct./Dec. 2015

Licenciado sob uma Licença Creative Commons

DOI: http://dx.doi.org.10.1590/0103-5150.028.004.A015

\title{
Workplace accommodation to people with disabilities: a case study in civil construction
}

\author{
Inclusão Laboral de trabalhadores com deficiência: \\ estudo de caso na construção civil
}

\author{
Bruno Guimarães, Laura Bezerra Martins, Béda Barkokébas Junior* \\ Universidade Federal de Pernambuco (UFPE), Departamento de Design, Pernambuco, RE, Brazil
}

\begin{abstract}
Objective: the aim of this paper was to assess and describe the various tasks of the jobs of servant of construction, bricklayer, painter and charge of construction in the civil construction to determine the profile of workers with disabilities who could perform these functions and what adjustments are needed. Methods: this research it is a descriptive cross-sectional quantitative approach. Direct observation of the activities performed at the construction site in each of the jobs evaluated and the environment; interviews with two workers each function evaluated, except painter there was only one worker, a civil engineer and a safety technician to describe detailed, together, as they were carried out each of the required tasks; a video and photographic record of tasks being carried out to analyze the jobs, ErgoDis/IBV software resources were used. At the time the research was conducted in the field, were working a total of 1,547 employees. Results: It was observed that workers with hearing impairments could perform the activities without any adaptations in the workplace and individuals who had had a leg or foot amputated need to use appropriate prostheses to perform the activities of the functions. Conclusion: only workers with full or partial hearing
\end{abstract}

* BG: PhD, e-mail: bmguimaraes@hotmail.com LBM: PhD, e-mail: laurabm@folha.rec.br BBJ: PhD, e-mail: bedalsht@upe.poli.br 
impairment could perform all the jobs analyzed without any accommodation in the workplace and individuals with amputation of leg or foot may only perform tasks using appropriate aids.

Keywords: Human Engineering. Occupational Health. People with disabilities. Job accommodation. Construction Industry.

\section{Resumo}

Objetivo: o objetivo do artigo foi avaliar e descrever as diversas tarefas dos postos de trabalho do servente, pedreiro, pintor letrista e encarregado de turma da construção civil para determinar o perfil dos trabalhadores com deficiência que poderiam exercer essas funções e quais as adaptações necessárias. Métodos: esta pesquisa trata-se de um estudo descritivo transversal de abordagem quantitativa. Foi utilizada observação direta das atividades realizadas no canteiro de obras em cada uma das funções avaliadas e do ambiente; entrevistas com dois trabalhadores de cada uma das funções avaliadas, com exceção do pintor letrista, que só havia um trabalhador, o trabalhador com deficiência, um engenheiro civil da obra e um técnico de segurança para descrever detalhadamente, em conjunto, como eram realizadas cada uma das tarefas prescritas; registro em vídeo e fotográfico da execução das tarefas e, para análise dos postos de trabalho, foram utilizados os recursos do software ErgoDis/IBV. No momento em que foi realizada a pesquisa de campo, estavam trabalhando na obra um total de 1.547 funcionários. Resultados: observou-se que os trabalhadores com deficiência auditiva poderiam exercer as atividades avaliadas sem nenhuma adaptação no ambiente de trabalho e que, para indivíduos com amputação de perna ou pé, seriam necessárias algumas adaptações. Considerações finais: apenas os trabalhadores com deficiência auditiva total e parcial poderiam exercer todas as funções analisadas sem nenhuma mudança no ambiente de trabalho e que os indivíduos com amputação de perna ou pé somente poderão exercer as tarefas nos postos de trabalho avaliados se utilizarem próteses adequadas.

Palavras-chave: Ergonomia. Saúde do Trabalhador. Pessoa com deficiência. Inclusão laboral. Indústria da Construção.

\section{Introduction}

People with disabilities (PD) account for about $15 \%$ of the world population, or one billion people (1). While in Brazil this figure is $23.9 \%$ of the population, i.e. there are 45.6 million PDs in Brazil. In northeastern Brazil, the amount of PD is a bit higher, $30.9 \%$ of the population, and the state of Pernambuco has $27.5 \%$ of the population (2). The highest amount of PD in the Northeast compared to the national average can be caused by a lower socioeconomic development and worse conditions of health care in the region.

The inclusion of this population in the sociallabor environment has been discussed and encouraged through various laws. Among the legal measures adopted by the State, the ones that stand out are Law No. 8.112, of 11/12/1990, which ensures PD the right that $20 \%$ of the places offered in competitive public entrance examinations, and the Law No. 8213/91 which obliges companies with more
100 than employees to have $2 \%$ to $5 \%$ of their staff as people with disabilities $(3,4)$. It is important to note that the state, despite require companies to include the PD and might to penalize them with fines, if not met the quota law does not provide tax incentives for Brazilian companies to hire and carry out the necessary adjustments of workplace to workers with disabilities.

Despite the attempts to include PD at work, the number of such people seeking employment and of those receiving job opportunities remains low in North America and Europe (5). In Brazil, this is also true, because it is seen that current legislation does not guarantee the inclusion of PD in the labor market, since, as per data from the 2012 Annual Report of Social Information (RAIS) (6), of the total of 47.1 million people with active, formal employment links at 31 December, 330,300 were declared as people with disabilities, which represents $0.7 \%$ of the total of formal employment links, ie, missing a lot to reach the percentage required by 
law. Unfortunately, workers with disabilities are very often seen as a problem to be dealt with instead of an opportunity that can be used (7).

Occupational and demographic data from the US Census Bureau and the Occupational Information Network data show that in the US, workers with disabilities are under-represented in jobs that require qualification and have good salaries. On the other hand, they are well represented in low-skilled jobs and low wages (8). In this context, despite the efforts, the PD at various times suffer prejudice for being seen as generating costs and low productivity.

Some companies have hired workers with disabilities without using appropriate methods to do so. Thus, there was no prior analysis of accessibility conditions, nor of the demands of their jobs, nor of these people's potential, resulting adaptation problems, occupational accidents and economic damage to the image and social awareness of the company, as well as psychosocial problems in relation to PD (9). In a survey conducted by Chi et al. (10), of the 540 case studies analyzed, in only 3 of them did employers conduct an analysis of the tasks and the functional abilities of workers with disabilities for job accommodation.

It is verified that job accommodation to people with disabilities is a tough task that has encountered some difficulties, such as the lack of offering professional training to people with disabilities, the presence of architectural and organizational barriers and discrimination regarding PD functional potential (11). Thus, it is essential to understand that the interaction between people with disabilities and the elements of the work system should be treated by a multidisciplinary team, since, the knowledge of the tasks, the physical, intellectual and organizational demands of jobs and knowing the functional capabilities of a worker with disability, reasonable adaptations to work environments can be carried out adequately.

Therefore, there is a need to compare the demands of the job and the PD's capabilities. The goal is that the demands of work do not exceed the functional capacities of the worker with a disability and that the workplace is accessible and safe. PD's jobs should allow or facilitate the development of their individual skills and abilities, while also preventing the progression of their existing deficiencies and/or the emergence of new ones (12). Thus, this avoids the worker with disabilities having to make a great effort to adapt to the job or the job falling far short of their professional qualifications (13).

Workplace accommodation to people with disabilities may vary both in the complexity of each case and in the resources needed. Consequently, planning for each adaptation also varies in time, effort and the number and the professionals involved. It is important to include physiotherapists, occupational therapists, doctors, safety at work engineers, architects, designers and other professionals. Moreover, the adaptation process should involve the people affected (the PD, the employer and co-workers) as active participants in obtaining a good result.

A workplace not adapted to the worker with a disability, just as to any worker, will bring losses to the company, such as a fall in productivity, an increase in absenteeism, a greater likelihood of work accidents and errors (14). Importantly no data on occupational accidents involving workers with disabilities in the construction industry in Brazil.

The construction industry plays an important role in generating direct and indirect jobs, especially for those with little professional skills (15). In addition, in the UK, there are many job opportunities in construction for workers with disabilities, however, only a small number of companies offer these positions to the PD (16). Despite the importance of this economic sector in Brazil, there is a lack of publications on labor inclusion of PD in this sector in the country (17).

The purpose of the paper was to assess and describe the various tasks of the laborer, bricklayer, painter and foreman of the construction industry to determine the profile of workers with disabilities who could perform such jobs and what adaptations are needed.

\section{Materials and methods}

This research is a cross-sectional descriptive study of quantitative approach. The field research was conducted at the site of a water supply network in the Metropolitan Region of Recife, in the state of Pernambuco, Brazil. The methods and techniques used in the field study were: direct observation of the activities performed at the construction site in each of the evaluated jobs and the environment, semistructured interviews (annex 1) with the workers and a video and photographic record of the tasks. 
To complement these techniques, in order to analyze the jobs of laborer, bricklayer, painter and foreman, ErgoDis/ IBV software resources were used. According to Ferreras et al. (18), it is a software used to adapt jobs to people with physical, mental and/ or sensory disabilities. The software was developed by the Institute of Biomechanics of Valencia (IBV) to make an ergonomic evaluation of jobs filled by PDs. It collects information of the physical, sensory, communication, intellectual and organizational demands of the tasks and functional and intellectual capacity of the subject in order to guide the evaluator in making decisions about the case and, if possible, on what adaptations to suggest (18).

By the time the field research was carried out, there was a total of 1,547 employees working on the site in various jobs, with observation and video registration of the execution of activities of three laborers, three bricklayers, one painter (there was only one working) and three foreman. In this sense, the field research was started to determine the actual work (activity) of the jobs based on the description of the prescribed work (task) provided by documents Working Conditions and Environment Program (PCMAT) and Technical Report of Environmental Conditions of Work (LTCAT). The LTCAT and the PCMAT aim to anticipate, recognize, evaluate and control environmental hazards that can cause diseases in the workplace. Because of that, it was asked randomly to two experienced workers from each of the evaluated jobs and the worker with disability, one civil engineer and a safety technician to describe in detail, together, as they were held each required tasks in PCMAT and LTCAT documents. No employee refused to participate. Moreover, these workers responded if each item of the physical, sensory, communication, intellectual and organizational demands that are presented in the software (17) were necessary to carry out the work activities of each job. This way, it was possible to fill in the information in the software about the physical and intellectual demands of the task.

Subsequently, photograph and video registration were made about the execution of each of the activities in each of the jobs evaluated. This step aimed to assist in the collection of data regarding the movements and postures adopted in conducting the activities to determine task demands. In the following section, it was determined the physical and intellectual demands of jobs through the software.
No information was found in the national literature on the major sequelae and/or disabilities caused by accidents at work in the construction industry. Through the verbal information provided by a Civil Engineer expert in Health and Safety in Construction Labour, it was possible to define the most common deficiencies caused by accidents at work in this productive sector, since this is an industry that employs few workers with disabilities. So, using the software, it was possible to simulate individuals with partial or total hearing loss; total and partial visual impairments; and amputation of the fingers, thumb, hand, arm, leg and foot to determine whether they could perform the jobs considered and which would the necessary adaptations be.

According to the analysis and interpretation of the data obtained from the software, it was possible to outline the causes for the inadequacies of the jobs and, finally, recommendations for the necessary adjustments were developed. This study was submitted to and approved by the Ethics Committee in Research of the Federal University of Pernambuco and given the registration number 315/10.

\section{Results}

For data collection were interviewed in all, 11 workers of the construction site. The real subject simulated in the software was laborer and had a partial hearing impairment and nine other hypothetical subjects with deficiencies determined by the study, by the software to check if they could perform the jobs of laborer, bricklayer, painter and foreman and what adaptations would be needed.

The real subject simulated in the software had a partial hearing impairment and the disability was classified as moderate deafness, i.e. the individual can hear in a range of 41-55 dB (A) (19). However, he did not use a hearing aid. The worker who was simulated as having a partial visual impairment had low vision, i.e. visual acuity of between $5 \%$ and $30 \%$ in the better eye, on using the best optical correction (19). The hypothetical subjects who were simulated as having had an arm, a hand, a leg and a foot amputated were considered as having had these structures totally amputated. Individuals whose fingers and thumb had been amputated were deemed to have totally lost four fingers but not the thumb, or to have totally lost their thumb, respectively. Thus they could not make the 
pincer movement and had difficulty gripping objects with that hand.

The working day on the site was Monday through Thursday from 07:00 to 17:00 and Friday from 07:00 to $16: 00$ with a one-hour break for lunch, totaling 44 hours per week. At the time the field research was being conducted, there were 92 laborers, 40 bricklayers, 4 foremen of civil construction and 1 painter distributed over the construction sites.

\section{Workplace analysis}

The laborer is the worker who performs various duties in the civil construction industry. However, in this real case of evaluation, the worker carries out his activities in the area of the everyday activities of the construction site, keeping and delivering tools and personal protection equipment (PPE) in addition to cleaning and tidying up the site. From the detailed description of how were carried out each required task in PCMAT and LTCAT documents it was possible to prepare Table 1.
G.C.A. has total hearing loss in his left ear and partial hearing loss in his right ear, and is classified as moderately deaf, but has no significant difficulties in communicating with other workers, due to the level of his disability, even though he does not use a hearing aid.

The function of the job evaluated of foreman is to command a squad of workers to clean the land that falls within the limits of the construction site. In addition to allocating tasks to team members, he determines which areas should be cleaned, which present risks to the population neighboring the site and sometimes helps in clearing the land with a chainsaw or machete. From the detailed description of how were carried out each required task in PCMAT and LTCAT documents it was possible to prepare Table 2.

Worker of painter function of the evaluated job performed the painting activities and gluing the boards and signs present at the construction site. In the Table 3 shows the description of the tasks and activities which was determined from the detailed description of how were carried out each required task in PCMAT and LTCAT documents.

Table 1 - Task vs. Activity of laborer

\begin{tabular}{|c|c|}
\hline Task & Activity \\
\hline $\begin{array}{l}\text { 1) Perform excavation and prepare mass of concrete and other } \\
\text { materials. }\end{array}$ & In this job, this task is not accomplished. \\
\hline 2) Perform demolition of concrete, masonry and other structures. & In this job, this task is not accomplished. \\
\hline 3) Assist in the activities of cargo handling and lifting. & In this job, this task is not accomplished. \\
\hline 4) Carry on signaling activity when prompted. & In this job, this task is not accomplished. \\
\hline $\begin{array}{l}\text { 5) Help professionals: carpenter, steel fixer, bricklayer, painter, } \\
\text { assembler, etc. When prompted. }\end{array}$ & In this job, this task is not accomplished. \\
\hline 6) Assist in cleaning and organizing of the area. & $\begin{array}{l}\text { a) Delivers, stores and organizes tools and PPEs in the } \\
\text { common area container (different movements of the upper } \\
\text { and lower). } \\
\text { b) Cleans and organizes the tables and chairs in the common } \\
\text { area (different movements of the upper and lower). } \\
\text { c) Organizes and stores the garbage from the common area } \\
\text { (different movements of the upper and lower). }\end{array}$ \\
\hline
\end{tabular}

Source: PCMAT, LTCAT and interviews. 
Table 2 - Task vs. Activity of foreman

\begin{tabular}{ll}
\hline \multicolumn{1}{c}{ Task } & Activity \\
\hline $\begin{array}{l}\text { 1) Plan, coordinate and control operations in production sites } \\
\text { 2) Distribute tasks according to the ability of each team }\end{array}$ & $\begin{array}{l}\text { a) Check the possibility of doing what the workflow manager } \\
\text { requests. } \\
\text { b) Verify if the land clearing at the site poses a risk to the } \\
\text { neighboring population. }\end{array}$ \\
$\begin{array}{l}\text { a) In addition to allocating tasks to employees verbally, at } \\
\text { times also performs land clearing using chainsaws and } \\
\text { machetes. }\end{array}$ \\
$\begin{array}{l}\text { b) Holds chainsaw with both hands and cuts what is } \\
\text { necessary (different movements of the upper limbs). } \\
\text { c) With his dominant hand holds the knife and makes } \\
\text { various movements of the upper limb to cut the necessary } \\
\text { vegetation. }\end{array}$
\end{tabular}

Source: PCMAT, LTCAT and interviews.

Table 3 - Task vs. Activity of painter

\begin{tabular}{|c|c|}
\hline Task & Activity \\
\hline $\begin{array}{l}\text { 1) Paint external and internal construction surfaces, scraping, } \\
\text { mashing and covering with one or more layers of paint }\end{array}$ & In this job, this task is not accomplished. \\
\hline 2) Create and paint all types of signs for signalling work & $\begin{array}{l}\text { a) If there is previous paint and there is need to remove the } \\
\text { paint, pours the chemical products on the sign (different } \\
\text { movements of the upper limb). } \\
\text { b) With the spatula, scrapes the paint of the sign to remove it } \\
\text { (various movements of the upper limb). } \\
\text { c) Holds the pencil with one hand and draws the letters on the } \\
\text { signs (various movements of the upper limb). } \\
\text { d) Dips the brush into the paint (different movements of the } \\
\text { upper limb). } \\
\text { e) Paints the marked letters with the brush (many of the upper } \\
\text { limb movements). } \\
\text { f) Cuts the adhesive with scissors with the help of one hand } \\
\text { holding the stickers on the workbench and the other handling } \\
\text { the scissors (various movements of the upper limb). } \\
\text { g) Positions the adhesive where indicated, with one arm } \\
\text { supports the adhesive and the other fixes the stickers and } \\
\text { slides on the sign }\end{array}$ \\
\hline
\end{tabular}

Source: PCMAT, LTCAT and interviews.

Bricklayers are characteristic construction professionals, and important for building concrete structures, masonry and doing finishing. In the job evaluated, the workers built foundations, concrete and masonry structures, and did finishing and applied cladding and screeded floors. From the detailed description of how were carried out each required task in PCMAT and LTCAT documents it was possible to prepare Table 4.

Assessments were made using the software to verify what workers with disabilities could perform the jobs of laborer, bricklayer, painter and foreman of the construction and what adaptations would be needed. This can be seen in Table 5 .

Based on results found by the software it is verified that in the real case, due to the level of hearing loss, the individual who exercised the job of laborer had no difficulty in communicating with other workers. Therefore, the result was acceptable without changes, which corroborated to what is observed in practice, where workers perform their work activities without difficulty. A subject with a similar disability to the real cases was also simulated in the software in the jobs of bricklayer, 
foreman and painter and the same result was obtained. However, if the level of the individual's hearing loss was greater, the use of a hearing aid, and communication through writing and sign language could be recommended.

In the hypothetical cases simulated, a person with a total hearing disability would have difficulty in communicating with other workers, but this can be overcome by communicating using sign language, by writing and lip-reading, which does not prevent him from performing the activities of all the jobs evaluated. Thus, the results were acceptable without changes. It is worth drawing attention to the research study by Williams et al. (20), in which $33 \%$ of workers with a hearing disability used hearing aids, $17 \%$ communicated through writing and $9 \%$ by using the sign language. Furthermore, individuals with a hearing disability had higher rates of employment (75\% of the sample) than people with other types of disability (21).

The hypothetical subjects with partial and total visual disability would present considerable difficulty due to the need for sight to undertake the tasks and to move around the construction site, so the results were determined as unacceptable for the jobs evaluated. According to Yeager (22), people who are unable to walk and the blind have lower employment rates. Moreover, in research of Newton and Ormerod (16), $21 \%$ of construction employers stated that they would hire a person with a visual disability even where the worker would have great difficulty in reading, with glasses.

Table 4 - Task vs. Activity of bricklayer

(to be continued)

\begin{tabular}{|c|c|}
\hline Task & Activity \\
\hline 1) Casting concrete & $\begin{array}{l}\text { a) When laying a joist, in a crouching position, he puts the battens in the desired locations (different } \\
\text { movements of the upper limbs). } \\
\text { b) Standing or squatting, holding with both hands the concrete pump, casts concrete in the place } \\
\text { indicated. } \\
\text { c) Depending on the type of concrete, he needs to thicken it, holding the hose of the vibrator with } \\
\text { both hands. } \\
\text { d) Squatting, he passes the ruler to level the concrete and make it smooth (different movements of } \\
\text { the upper limbs). } \\
\text { e) After the concrete is cured, if necessary, he undertakes the finishing (described in next item). }\end{array}$ \\
\hline 2) Doing finishing & $\begin{array}{l}\text { a) With a trowel in one hand, he picks up the mortar in the wheelbarrow and puts it in the place } \\
\text { where the finish will be done (different movements of the upper limbs). } \\
\text { b) Passes the trowel to level the place of the finishing (different movements of the upper limb). } \\
\text { c) Removes excess mortar and puts it back in the wheelbarrow (different movements of the upper } \\
\text { limb). } \\
\text { d) In finishing with a tamper, he grips it with one hand and passes it over the concrete to give the } \\
\text { finishing (diverse movement of the upper limb). }\end{array}$ \\
\hline 3) Constructing foundations & $\begin{array}{l}\text { a) Standing or squatting, holding with both hands the concrete pump, he casts concrete into the } \\
\text { excavated site. } \\
\text { b) Depending on the type of concrete, he needs to thicken it, holding the hose of the vibrator with } \\
\text { both hands. } \\
\text { c) After the concrete has set and the moulds are removed, he does the finishing, if necessary } \\
\text { (already described). }\end{array}$ \\
\hline
\end{tabular}


Table 4 - Task vs. Activity of bricklayer

(conclusion)

Task

4) Building masonry structures

Putting up cladding and laying sub-flooring
Activity

a) Standing, he picks up the mortar from the wheelbarrow with the trowel, placing it under the spot where the brick will be placed. If there is already a brick there, he puts it on top of it (different movements of the upper limb).

b) Removes the brick from the ground by hand (different movements of the upper limb and trunk).

c) Puts the brick in place (different movements of the upper limb).

d) Beat with the trowel on top of the brick (elbow flexion-extension).

e) Removes the excess mortar around the brick (various movements of the upper limb).

f) Returns the excess mortar to the wheel-barrow (different movements of the upper limb).

g) Visually checks the brick is in place.

h) Checks the plumb.

i) May break a brick to fill space (different movements of the upper limb).

a) Crouching, he puts the batten in the desired locations (different movements of the upper limbs).

b) He throws mortar on the location indicated (various movements of the upper limb).

c) Spreads the mortar with the trowel (different movements of the upper limb).

d) After the mortar has set, he lays ceramic tiles on it (different movements of the upper limb).

e) Beats with his hand or with a rubber mallet on the ceramic to make it settle better (different movements of the upper limb).

f) Checks the alignment.

g) May need to cut the ceramic to make corners. Leans with one hand on the ceramic and with the other handles the Makita power cutter or manual tile-cutter to cut the ceramic to the correct degree.

h) Application of grouting (different movements of the upper limb).

Source: PCMAT, LTCAT and interviews.

Table 5 - Results of the evaluations through software

(to be continued)

\begin{tabular}{lllll}
\hline Job/disability & Laborer & Foreman & Bricklayer & Painter \\
\hline Partial hearing disability & $\begin{array}{l}\text { Acceptable without changes } \\
\text { ("real” case) }\end{array}$ & $\begin{array}{l}\text { Acceptable without } \\
\text { changes }\end{array}$ & $\begin{array}{l}\text { Acceptable without } \\
\text { changes }\end{array}$ & $\begin{array}{l}\text { Acceptable without } \\
\text { changes }\end{array}$ \\
\hline Total hearing disability & Acceptable without changes & $\begin{array}{l}\text { Acceptable without } \\
\text { changes }\end{array}$ & $\begin{array}{l}\text { Acceptable without } \\
\text { changes }\end{array}$ & $\begin{array}{l}\text { Acceptable without } \\
\text { changes }\end{array}$ \\
\hline Partial visual disability & Unacceptable & Unacceptable & Unacceptable & Unacceptable \\
\hline Total visual disability & Unacceptable & Unacceptable & Unacceptable & Unacceptable \\
\hline Thumb amputated & Acceptable without changes & $\begin{array}{l}\text { Acceptable with } \\
\text { changes }\end{array}$ & Unacceptable & $\begin{array}{l}\text { Acceptable with } \\
\text { changes }\end{array}$ \\
\hline Fingers amputated & Acceptable without changes & $\begin{array}{l}\text { Acceptable with } \\
\text { changes }\end{array}$ & Unacceptable & $\begin{array}{l}\text { Acceptable with } \\
\text { changes }\end{array}$ \\
\hline Hand amputated & Unacceptable & $\begin{array}{l}\text { Acceptable with } \\
\text { changes }\end{array}$ & Unacceptable & $\begin{array}{l}\text { Acceptable with } \\
\text { changes }\end{array}$ \\
\hline Arm amputated & Unacceptable & $\begin{array}{l}\text { Acceptable with } \\
\text { changes }\end{array}$ & Unacceptable & $\begin{array}{l}\text { Acceptable with } \\
\text { changes }\end{array}$ \\
\hline
\end{tabular}


Table 5 - Results of the evaluations through software

(conclusion)

\begin{tabular}{lllll}
\hline Job/disability & Laborer & Foreman & Bricklayer & Painter \\
\hline Leg amputated & Acceptable with changes & $\begin{array}{l}\text { Acceptable with } \\
\text { changes }\end{array}$ & $\begin{array}{l}\text { Acceptable with } \\
\text { changes }\end{array}$ & $\begin{array}{l}\text { Acceptable with } \\
\text { changes }\end{array}$ \\
\hline Foot amputated & Acceptable with changes & $\begin{array}{l}\text { Acceptable with } \\
\text { changes }\end{array}$ & $\begin{array}{l}\text { Acceptable with } \\
\text { changes }\end{array}$ & $\begin{array}{l}\text { Acceptable with } \\
\text { changes }\end{array}$ \\
\hline
\end{tabular}

Source: research results through the software.

Regarding workers whose arm and hand had been amputated, the simulation results were unacceptable for laborer and bricklayer because the activities done required handling of tools and objects with upper limbs. However, these individuals could perform the job of foreman, if this could be done without using a chain-saw to clear the land, so the result was acceptable if considered with some changes. The job of painter, was also found acceptable if considered with some changes, i.e. for the individual to carry out the activities of the function he would need to request assistance from another employee to undertake the activity of fixing boards and signs.

In the findings of Stoddard (23), 64\% of the employers that had adapted jobs to PDs said that they had redistributing non-essential tasks to other workers. While in the research of Newton and Ormerod (16), 73\% of employers in the construction industry made adaptations in work organization to PD (e.g. transferring disabled people to other jobs, rearranging work duties). Thus, the redistribution of tasks and requesting help from another employee to perform non-essential tasks were useful adaptations to have in mind when including people with disabilities at work.

In the cases of workers whose thumb or fingers had been amputated, the results were unacceptable for the job of bricklayer, because the activities to be performed required strength in both hands. However, for individuals whose fingers or thumb have been amputated, the result was acceptable without changes for the role of laborer, because when he needs to pick up the tools with both hands, he could support them with his deficient hand in a claw movement and with his other hand, he could hold objects and tools so as to store them or take them to employees. In the job of foreman, the hypothetical subjects whose fingers or thumb have been amputated could undertake the activities, but not clear the land with the chainsaw, so the result was acceptable with changes. In the function of painter, the result was similar to the previous one where workers whose fingers or thumb have been amputated could carry out the activities of the function if they used adequate finger or thumb prostheses, which would enable them to make the partial movement of the pincer and claw, or else, they could ask for help from another employee for the activity of fixing boards and signs.

In the hypothetical case of workers whose leg or foot had been amputated, they could carry out activities in all the jobs evaluated if they used appropriate prosthesis for the leg or foot, which would facilitate their moving around the construction site and enable them to handle tools when they move and are standing because when they use crutches, their hands are in use to hold them. The use of assistive technology will enable job tasks to be done, thus increasing employment opportunities for PD $(24,25)$.

Thus, it is noted that in this research the adjustments needed so that disabled workers might adequately carry out the tasks were low cost, such as redistributing tasks and using prostheses. These results are in agreement with Young (26), whose studies have evaluated the costs of job accommodation, with most costs relatively low compared to the benefits.

The findings of Unger and Kregel (27) in the 43 large companies that employed PD, the majority (78\%) reported that the average cost of labor adjustments was less than 100 dolars. Schartz et al. (28) published the results of 259 companies that had made adaptations of the job for PD and found that in the first year after the accommodation, 49.4\% of the employers said they had not spent anything on adaptations. As to the others, the average cost in the first year was $\$ 600$. Additionally, the estimates for the direct benefits obtained such as, increased 
productivity and a decrease in absenteeism from 0 to $\$ 116,000$, with an average of $\$ 1,000$.

In the study by Solovieta et al. $(29,30)$, the main benefits obtained by companies based on job accommodation to individuals with disabilities were: retaining skilled workers, an increase in worker productivity, eliminating the costs of training new employees, improving relations between workers, and an increase in the morale and general productivity of the company.

Consequently, it is verified that is not always necessary to make major physical changes in the work environment nor to provide sophisticated, technological aids to adapt the workplace to an individual with disability. Starting with organizational changes such as, the redistribution of tasks, changes in working hours and the provision of suitable prostheses and orthoses, it is possible to achieve the accommodation of workers with disabilities.

\section{Conclusion}

Through knowledge of the tasks, the physical, intellectual and organizational demands of workplaces and knowing the functional capabilities of a worker with disability, reasonable adaptations to work environments can be carried out adequately. To achieve this goal, it is important that this is done through an integration of a multidisciplinary team, which involves the areas of occupational safety and ergonomics in order to enable the survey, data analysis, besides physical, intellectual and organizational recommendations.

The survey results showed that only workers with total and partial hearing loss could undertake the jobs of laborer, bricklayer, painter and foreman without any change in the work environment, and individuals whose leg or foot had been amputated can only perform tasks in the jobs evaluated if they use adequate leg or foot prostheses.

The study has some limitations, such as the fact that it has only evaluated one real case and various hypothetical cases and also for not having evaluated the accessibility of workers with disabilities from their home to the workplace, which is a major issue especially for workers with visual and physical disabilities.

Due to the lack of literature on the topic of the workplace accommodation of people with disabilities in the construction industry, it is recommended that further studies in this production sector are undertaken and deepened, especially to focus on accessibility and worker productivity, with the aim of fostering the process of employing individuals with disabilities and facilitating compliance with the law on quotas.

In this context, it is emphasized the importance of studies in this industry, because it involves high risk activity, level 4, according to Regulatory Standard no 4 that addresses to the Specialized Services in Safety Engineering and Occupational Medicine.

\section{Acknowledgements}

This paper is an part of the Master's dissertation entitled "Exigência da tarefa e o perfil dos trabalhadores com deficiência: um estudo de caso na construção civil usando o software ErgoDis/IBV" ("Requirement of the task and the profile of workers with a disability: a case study in civil construction using ErgoDis/IBV software", undertaken by Bruno Maia de Guimarães, and supervised by Laura Bezerra Martins. Post-Graduate Program in Design at Federal University of Pernambuco, 2011. Financial support received from CAPES.

\section{References}

1. World Health Organization (WHO). World report on disability 2011. Genebra: World Health Organization. (2011)

2. Instituto Brasileiro de Geografia e Estatística (IBGE Brazilian Institute of Geography and Statistics). Censo Demográfico 2010 [Demographic Census 2010]. Rio de Janeiro: IBGE, 2011.

3. Lei no ${ }^{8.112 . ~ B r a z i l . ~ B r a s i l i a ~(D F): ~ I m p r e n s a ~ N a c i o n a l . ~}$ (Dec 11, 1990).

4. Lei no 8.213. Brazil. Brasilia (DF): Imprensa Nacional. (Jul 24, 1991).

5. Westmorland MG, Williams R. Employers and policy makers can make a difference to the employment of persons with disabilities. Disabil Rehabil. 2002; 24(15): 802-9. 
6. Brazil. Ministério do Trabalho e Emprego [Ministry of Labor and Employment]. Relação anual de informações sociais - Rais, 2000 a 2012 [Annual Report on Social Information, 2000 to 2012].

7. Morton L, Foster L, Sedlar J. Managing the mature workforce. New York: The Conference Board; 2005.

8. Kaye HS. Stuck at the bottom rung: occupational characteristics of workers with disabilities. J Occup Rehabil. 2009;19(2):115-28.

9. Simonelli AP, Camarotto J. Analysis of industrial tasks as a tool for the inclusion of people with disabilities in the work market. Occup Ther Int. 2008;15(3):150-64.

10. Chi CF, Pan JS, Liu TH, Jang, Y. The development of a hierarchical coding scheme and database of job accommodation for disabled workers. Int J Ind Ergonom. 2004;33:429-47.

11. Guimarães BM, Martins LB, Barkokébas Junior, B. Issues concerning scientific production of including people with disabilities at work. Work. 2012;41(Suppl 1):4722-8.

12. Tortosa L, et al. Ergonomia y discapacidad. Madrid: Ministerio de Trabajo y Asuntos Sociales; 1997.

13. Martins LB, Barkokébas Junior B, Guimarães, BM. Including people with disabilities at work: a case study of the job of bricklayer in civil construction in Brazil. Work. 2012;41(Suppl 1):4716-21.

14. Oliveira SCF, Tomaz AF, Barbosa Filho AB, Lucena NMG, Gualberto Filho A. Adaptação de postos de trabalho ocupados por pessoas portadoras de deficiência física. In: 11ํㅡㄹ Congresso Brasileiro de Ergonomia; 2001 [anais]. Gramado: ABERGO; 2001.

15. SINDUSCON/PE - Sindicato da indústria da construção civil no estado de Pernambuco. 0 construtor. Edição especial II. Recife: SINDUSCON/PE; 2003.

16. Newton R, Ormerod M. Do disabled people have a place in the UK construction industry? Construction Management and Economics. 2005;23:1071-81.

17. Guimarães BM. Exigências da tarefa e o perfil dos trabalhadores com deficiência: um estudo de caso na construção civil usando o software ErgoDis/IBV [dissertation]. Pernambuco: University of Pernambuco; 2011.

18. Ferreras A et al. Ergonomic adaptation of workplaces for people with disabilities: case studies. In: Proceedings IEA Congress - Meeting Diversity in Ergonomics, 2006, Anais, Eur. Erg. Elsevier Ltd; 2006.
19. Brazil. Decreto 3.298. Política Nacional para Integração da pessoa com deficiência [Decree 3.298, National Policy for Integration of the Handicapped]. Brasilia DF: Imprensa Nacional; 1999.

20. Williams M, Sabata D, Zolna J. User needs evaluation of workplace accommodations. Work. 2006;27:355-62.

21. Dutta A, Gervey R, Chan F, Chou CC, Ditchman, N. Vocational rehabilitation services and employment outcomes for people with disabilities: A United States Study. J Occup Rehabil. 2008;18:326-34.

22. Yeager P, Kaye HS, Reed M, Doe TM. Assistive technology and employment: experiences of Californians with disabilities. Work. 2006;27:333-44.

23. Stoddard S. Personal assistance services as a workplace accommodation. Work. 2006;27:363-9.

24. Langton AJ, Ramseur H. Enhancing employment outcomes through job accommodation and assistive technology resources and services. J Vocat Rehab. 2001; 16(1):27-37.

25. Schwanke TD, Smith RO. Assistive technology outcomes in work settings. Work. 2005;24:195-204.

26. Young AJ. The evolution of personal assistance services as a workplace support. J Vocat Rehab. 2003;1:73-80.

27. Unger D, Kregel J. Employers' knowledge and utilization of accommodations. Work. 2003;21:5-15.

28. Schartz HA, Hendricks DJ, Blanck P. Workplace accommodations: evidence based outcomes. Work. 2006; 27:345-54.

29. Solovieva TI, Walls RT, Hendricks DJ, Dowler DL. Cost of workplace accommodations for individuals with disabilities: with or without personal assistance services. Disabil Health J. 2009;2:196-205.

30. Solovieva TI, Dowler DL, Walls RT. Employer benefits from making workplace accommodations. Disabil Health J. 2011;4:39-45.

Received: 04/26/2012 Recebido: 26/04/2012

Approved: 05/28/2015 Aprovado: 28/05/2015 
Guimarães B, Martins LB, Junior Barkokébas B.

\section{Annex 1}

Semistructured interviews

1. Job performed:

2. Describe step by step each of the tasks that are performed in the job.

Task 1:

Task 2:

Task 3:

Task 4:

Task 5: 
